Leaflets on Philippine botany.-Under this title A. D. E. Elmer proposes to issue in serial form articles on Philippine plants, both scientific and economic, printed in English, Latin, German, or French. This publication will appear at irregular intervals, at a subscription price of $\mathrm{x} \frac{3}{4}$ cents per page, and may be obtained by addressing the editor at Manila. The first issue is a paper of $4^{\mathrm{I}}$ pages entitled Philippine Rubiaceae, by the editor, containing ${ }^{5} 5^{\circ}$ species, of which 45 are new, representing 42 genera.-J. M. C.

Das Pflanzenreich. ${ }^{3}$ - Part 26 contains the Droseraceae by L. Diels. Drosophyllum, Dionaea, and Aldrovanda are regarded as monotypic genera; while Drosera is credited with 84 species, 5 of which are new. A very full discussion of structure and range precedes the synopsis.-J. M. C.

Pflanzenfamilien.4-Part 224 includes the completion of the Spiridentaceae, the Lepyrodontaceae, and the Pleurophascaceae, and a portion of the Neckeraceae, all by V. F. Brotherus. Part 225 continues the Ascolichenes by A. ZAHLBRUCKNER.-J. M. C.

\title{
NOTES FOR STUDENTS.
}

Revelations of the ultramicroscope.-GAIDUKov has been seeing previously invisible things by means of SEIDENTOPF's ultramicroscope, and hastens to communicate them in two preliminary papers. ${ }^{5}$ After mastering the rather difficult technique and the sources of error, he began by observing the expressed contents of a Vaucheria filament, but later found that it was possible to observe the contents in situ. He saw the ultramicroscopic particles of plasma and chlorophyll, the former white and blue, the latter red and green-colors whose significance is unknown as yet for lack of sufficient physical investigation of the instrument. He watched the collision of plasma particles with structureless oil drops and their recoil, and the like collisions of chlorophyll particles and their disappearance in the oil, in which the number of red and green chlorophyll granules steadily increased. This appears to be actually the formation of a colloidal solution of chlorophyll in oil-an oleosol.

In examining a living filament he found that the protoplasm occupied a much greater space than appears with ordinary illumination, only a very small part of the filament being optically empty. In the chloroplasts of Mesoçarpus, roundish or stellate flecks of chlorophyll particles are distributed through the stroma, whose structure is like that of the protoplasm; there is no indication of the soluticn of chlorophyll in oil droplets lying in the stroma-a widely accepted notion.

3 Engler, A., Das Pflanzenreich. 26 Heft. Droseraceae von L. Diels. pp. 136. figs. 40 (286), map I. Leipzig: Wilhelm Engelmann. I906. M 6.80.

4 Engler, A. und Prantr, K., Die natürlichen Pflanzenfamilien. Lieferungen 224 and 225. Leipzig: Wilhelm Engelmann. 1906.

5 GaIdukov, N., Untersuchungen mit Hilfe des Ultramikroskopes nach Seidentopf. Ber. Deutsch. Bot. Gesells. 24:107-112, 155-157. 1906. 


\section{$2 \mathrm{BHL}$ Biodiversity Heritage Library}

1906. "Leaflets on Philippine Botany." Botanical gazette 42(3), 223-223. https://doi.org/10.1086/328965.

View This Item Online: https://www.biodiversitylibrary.org/item/94881

DOI: https://doi.org/10.1086/328965

Permalink: https://www.biodiversitylibrary.org/partpdf/223246

\section{Holding Institution}

Missouri Botanical Garden, Peter H. Raven Library

\section{Sponsored by}

Missouri Botanical Garden

\section{Copyright \& Reuse}

Copyright Status: Public domain. The BHL considers that this work is no longer under copyright protection.

This document was created from content at the Biodiversity Heritage Library, the world's largest open access digital library for biodiversity literature and archives. Visit BHL at https://www.biodiversitylibrary.org. 